\title{
A comparative multidimensional LC-MS proteomic analysis reveals mechanisms for furan aldehyde detoxification in Thermoanaerobacter pseudethanolicus 39E
}

\author{
Sonya M Clarkson 1,2, Scott D Hamilton-Brehm ${ }^{1,2,4}$, Richard J Giannone ${ }^{1,3}$, Nancy L Engle ${ }^{1,2}$, Timothy J Tschaplinski, ${ }^{1,2}$
} Robert L Hettich ${ }^{1,3}$ and James G Elkins 1,2* $^{1,2}$

\begin{abstract}
Background: Chemical and physical pretreatment of lignocellulosic biomass improves substrate reactivity for increased microbial biofuel production, but also restricts growth via the release of furan aldehydes, such as furfural and 5-hydroxymethylfurfural (5-HMF). The physiological effects of these inhibitors on thermophilic, fermentative bacteria are important to understand; especially as cellulolytic strains are being developed for consolidated bioprocessing (CBP) of lignocellulosic feedstocks. Identifying mechanisms for detoxification of aldehydes in naturally resistant strains, such as Thermoanaerobacter spp., may also enable improvements in candidate CBP microorganisms.

Results: Thermoanaerobacter pseudethanolicus 39E, an anaerobic, saccharolytic thermophile, was found to grow readily in the presence of $30 \mathrm{mM}$ furfural and $20 \mathrm{mM} 5-\mathrm{HMF}$ and reduce these aldehydes to their respective alcohols in situ. The proteomes of T. pseudethanolicus 39E grown in the presence or absence of $15 \mathrm{mM}$ furfural were compared to identify upregulated enzymes potentially responsible for the observed reduction. A total of 225 proteins were differentially regulated in response to the $15 \mathrm{mM}$ furfural treatment with 152 upregulated versus 73 downregulated. Only 87 proteins exhibited a twofold or greater change in abundance in either direction. Of these, 54 were upregulated in the presence of furfural and 33 were downregulated. Two oxidoreductases were upregulated at least twofold by furfural and were targeted for further investigation. Teth39_1597 encodes a predicted butanol dehydrogenase (BdhA) and Teth39_1598, a predicted aldo/keto reductase (AKR). Both genes were cloned from T. pseudethanolicus 39E, with the respective enzymes overexpressed in E. coli and specific activities determined against a variety of aldehydes. Overexpressed BdhA showed significant activity with all aldehydes tested, including furfural and 5-HMF, using NADPH as the cofactor. Cell extracts with AKR also showed activity with NADPH, but only with four-carbon butyraldehyde and isobutyraldehyde.
\end{abstract}

Conclusions: T. pseudethanolicus 39E displays intrinsic tolerance to the common pretreatment inhibitors furfural and 5-HMF. Multidimensional proteomic analysis was used as an effective tool to identify putative mechanisms for detoxification of furfural and 5-HMF. T. pseudethanolicus was found to upregulate an NADPH-dependent alcohol dehydrogenase 6.8-fold in response to furfural. In vitro enzyme assays confirmed the reduction of furfural and 5-HMF to their respective alcohols.

Keywords: Thermophiles, Lignocellulosic, Biofuels, Proteomics, Inhibitor, Pretreatment, Furfural, 5-hydroxymethylfurfural, Butanol dehydrogenase

\footnotetext{
* Correspondence: elkinsjg@ornl.gov

${ }^{1}$ BioEnergy Science Center, Oak Ridge National Laboratory, Oak Ridge, TN

37831-6341, USA

${ }^{2}$ Biosciences Division, Oak Ridge National Laboratory, Oak Ridge, TN

37831-6341, USA

Full list of author information is available at the end of the article
} 


\section{Background}

Thermophilic bacteria, such as Clostridium thermocellum and Caldicellulosiruptor species have gained interest for their possible use as biocatalysts for converting lignocellulosic biomass into renewable fuels and chemicals [1-4]. The potential advantages of thermal bioprocessing include improved kinetics, reduced viscosities of concentrated slurries, lower oxygen solubility, and reduced process cooling requirements [2]. In addition, several bacterial phyla include thermophiles that are able to utilize plant cell walls directly through the action of complex (hemi)cellulase systems expressed either as free enzymes, cellulosomes, or multifunctional enzymes [5]. Relying on these native enzymes in a bioprocessing scheme could substantially reduce or even eliminate the need for exogenous enzymes for cellulose solubilization with a resulting improvement in process economics $[3,6,7]$.

To render plant material more reactive to microbial or enzymatic digestion, physical and chemical pretreatment methods are generally applied, and improvement in pretreatment technologies remains a highly active field of research $[8,9]$. Pretreatment with dilute acid at high temperatures has the benefit of solubilizing the hemicellulose fraction of biomass, which produces fermentable C5 oligomers and monomers [9]. However, one disadvantage of dilute acid pretreatment is that the process is non-specific and, depending on its severity, generates a number of toxic by-products [10]. Inhibitory compounds generated by dilute acid pretreatment typically fall into four categories: organic acids (acetic acid, ferulic acid), ketones (acetovanillone), phenolics (coniferyl alcohol, catechol), and aldehydes (furfural, hydroxymethylfurfural, vanillin). Mixtures of inhibitors, especially those including the furan aldehyde furfural, often have a synergistic effect on inhibiting cell growth and fermentation. For example, furfural increases the toxicity of acetate in yeast [11] and phenols in Escherichia coli [12,13]. Furfural is estimated to be responsible for $33 \%$ of the toxic effect of sugar cane hydrolysate on E. coli LYO1 [14].

In order to compete with more robust ethanologens such as Saccharomyces cerevisiae, several limitations inherent to fermentative thermophilic bacteria must be overcome. These limitations include relatively low ethanol titer and yield from mixed-acid fermentation pathways, although breakthroughs in metabolic engineering have improved the yield of ethanol from carbohydrates in some thermophiles to near theoretical limits [15]. Another major hurdle for thermophilic bioprocessing is growth inhibition by a wide range of compounds encountered in biomass fermentations. Insights into overcoming endproduct inhibition in $C$. thermocellum have recently emerged [16,17]; however, growth inhibition from other biomass-derived compounds remains underexplored in thermophilic microbes relative to S. cerevisiae [18-20] or engineered strains of $E$. coli [12,21-23]. Interestingly, members of the genus Thermoanaerobacter have been shown to tolerate pretreated biomass hydrolysates [24,25], and engineered strains give improved ethanol yields from both C5 and C6 sugars [26]. These properties have encouraged the development of several Thermoanaerobacter species for bioethanol production from hydrolysates (primarily xylose) and on cellulose when paired with a cellulolytic partner [27]. While surveying thermophilic bacteria for intrinsic tolerance to furfural (unpublished), we observed robust growth and rapid reduction of the compound by Thermoanaerobacter pseudethanolicus 39E (formally known as T. ethanolicus [28]). This study aims to identify and characterize traits that enable this organism to grow in the presence of and to simultaneously detoxify furan aldehydes through reduction to less toxic alcohols.

\section{Results and Discussion}

\section{T. pseudethanolicus 39E furan aldehyde tolerance}

We initially investigated the growth tolerance of T. pseudethanolicus 39E to the furan aldehydes furfural and 5-hydroxymethylfurfural (5-HMF). The addition of $10 \mathrm{mM}$ and $15 \mathrm{mM}$ furfural increased specific growth rates to $0.52 \pm 0.03 \mathrm{~h}^{-1}$ and $0.49 \pm 0.01 \mathrm{~h}^{-1}$, respectively, versus the control at $0.38 \pm 0.01 \mathrm{~h}^{-1}$ (Figure 1A). 5-HMF also stimulated growth at $10 \mathrm{mM}$ compared to no addition $(0.51 \pm$ 0.03 versus $0.41 \pm 0.02 \mathrm{~h}^{-1}$ ), while growth rates were similar to the control at $15 \mathrm{mM} 5$ - $\mathrm{HMF}(0.45 \pm 0.02$ versus $0.41 \pm$ $0.02 \mathrm{~h}^{-1}$; Figure 1B). Both $10 \mathrm{mM}$ furfural and 5-HMF slightly increased cell yield at $12 \mathrm{~h}$ by approximately $11 \%$ and $12 \%$, respectively (Figure 1). Higher growth rates and increased cell yield from the addition of subinhibitory concentrations of furfural and 5-HMF suggest that 39E metabolism is constrained by electron flow, which is relieved by the furan aldehydes serving as an alternative dissimilatory electron acceptor. The concentration resulting in $50 \%$ inhibition of growth $\left(\mathrm{IC}_{50}\right)$ with furfural was $30 \mathrm{mM}$ after $12 \mathrm{~h}$ and 30 to $40 \mathrm{mM}$ after $24 \mathrm{~h}$. The $\mathrm{IC}_{50}$ for 5-HMF was between 20 and $30 \mathrm{mM}$ after both 12 and $24 \mathrm{~h}$. As shown in Table 1, the determined values are comparable to or slightly higher than those of other thermophilic bacteria, while they are higher than reported values for E. coli, S. cerevisiae, and Zymomonas mobilis. Though direct comparisons are difficult due to differences in the growth conditions used in the various studies, these results suggest that T. pseudethanolicus 39E has a comparable if not higher tolerance to the furan aldehydes furfural and 5-HMF than other studied organisms.

\section{Furan aldehyde reduction and glucose fermentation}

In order to establish the mechanism of increased furan aldehyde tolerance, $T$. pseudethanolicus 39E was grown in the presence and absence of $15 \mathrm{mM}$ furfural or 5-HMF and the furan aldehyde and respective furan 

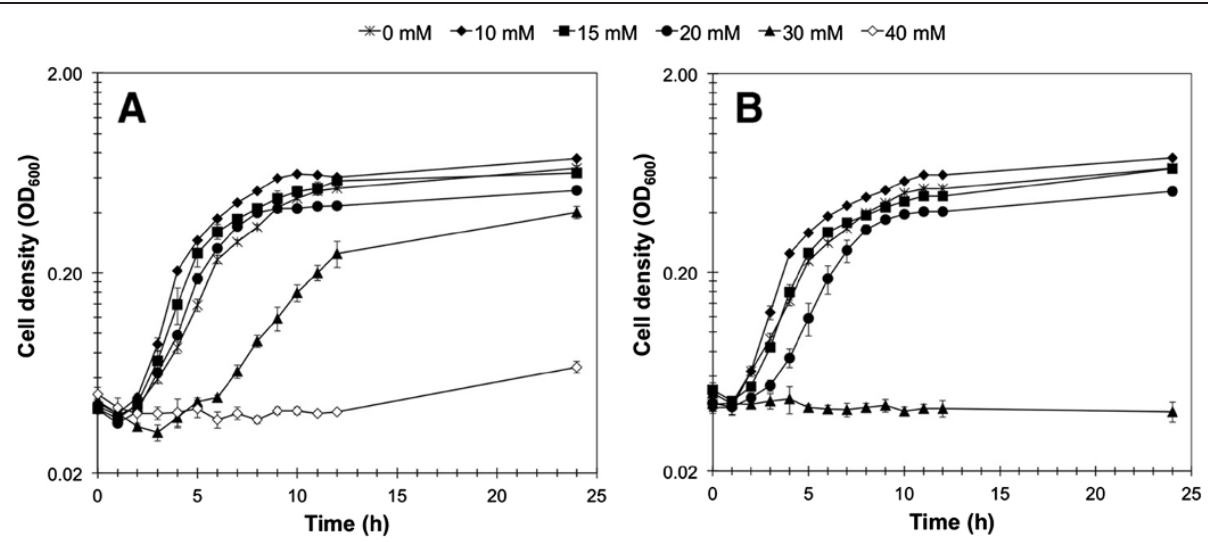

Figure $1 \mathrm{~T}$. pseudethanolicus furan aldehyde tolerance. T. pseudethanolicus was grown at $65^{\circ} \mathrm{C}$ with $40 \mathrm{mM}$ glucose and increasing concentrations of (A) furfural or (B) 5-HMF. Growth was measured by optical density at $600 \mathrm{~nm}$. Error bars are the standard deviation of three replicate cultures.

alcohol concentrations were measured. As shown in Figure 2, concomitant with growth, furfural and 5-HMF concentrations decreased while 2,5-furandimethanol concentration increased, indicating that T. pseudethanolicus 39E reduced 5-HMF to 2,5-furandimethanol. Furfural was most likely also reduced to furfuryl alcohol; however, quantitation of this compound is complicated by its polymerization at the growth temperature of T. pseudethanolicus 39E.

The addition of furan aldehydes affected end-product formation by T. pseudethanolicus 39E, as determined by HPLC analysis (Figure 3). At $10 \mathrm{mM}$ concentrations, more acetate and lactate are produced, while ethanol production remains constant. At furan aldehyde concentrations above $10 \mathrm{mM}$ where growth is observed $(15,20,30 \mathrm{mM}$ furfural and 15, $20 \mathrm{mM}$ 5-HMF), ethanol decrease and acetate increase are directly proportional, suggesting that acetyl coenzyme A is converted to acetate through phosphotransacetylase (PTA) and acetate kinase (AK) rather than serving as an electron acceptor for ethanol production via $\mathrm{NAD}(\mathrm{P}) \mathrm{H}$-dependent bifunctional alcohol dehydrogenase (ADH) activity. T. pseudethanolicus 39E possesses seven ADHs, but ethanol is primarily produced from NADPHdependent AdhB [34-36]. The oxidative branch of the pentose phosphate pathway is also present in 39E, which could supply NADPH [34]. Reduction of furfural/5-HMF to their corresponding alcohols during growth competes with ethanol production for electrons delivered by NADPH. This is also suggested by stoichiometric shifts in end products, where added aldehydes resulted in about a 0.5 times decrease in corresponding molar ethanol concentrations (that is, the $30 \mathrm{mM}$ furfural addition resulted in a decrease of $15 \mathrm{mM}$ ethanol versus the control). This shift in ethanol/ acetate concentrations is consistent with an electron balance

Table $1 \mathrm{IC}$ 50 $(\mathrm{g} / \mathrm{L}) *$ for furfural and 5-hydroxymethylfurfural in thermophilic bacteria and ethanologenic microorganisms

\begin{tabular}{|c|c|c|c|c|c|c|c|c|}
\hline Organism & Furfural & 5-HMF & YE $(\% \mathrm{w} / \mathrm{v})$ & Carbon (\% w/v) & Time (h) & Temp $\left({ }^{\circ} \mathrm{C}\right)$ & $\mathrm{pH}$ & Ref. \\
\hline T. pseudethanolicus 39E & 3 & $2-3$ & 0.1 & 0.7 & 12 & 65 & 7.0 & TS \\
\hline T. pseudethanolicus 39E & $3-4$ & $2-3$ & 0.1 & 0.7 & 24 & 65 & 7.0 & TS \\
\hline Bacillus coagulans MXL-9 & $2.5-5$ & 5 & $0.5^{\#}$ & $5-10$ & 24 & 50 & 7.0 & [29] \\
\hline C. saccharolyticus & $1-2$ & $1-2$ & 0.1 & 1 & 16,40 & 72 & 7.0 & {$[30]$} \\
\hline Thermoanaerobacterium strain $\mathrm{AK}_{1} 7^{\dagger}$ & 2 & 3 & 0.2 & 0.4 & 120 & 60 & 6.0 & [11] \\
\hline Tm. thermosaccharolyticum & 1.25 & 1 & 0.2 & 1 & 40 & 60 & 7.0 & [31] \\
\hline Thermotoga neapolitana & $2-4$ & $2-4$ & 0.1 & 1 & 16,40 & 80 & 7.0 & {$[30]$} \\
\hline E. coli LY180 & $1-1.5$ & nd & none & 5 & 48 & 37 & 6.5 & [23] \\
\hline E. coli LY180 & $<0.4$ & nd & none & $5(x y l)$ & 48 & 37 & 6.5 & [23] \\
\hline E. coli LY180 & 1.5 & nd & 0.1 & $5(x y l)$ & 48 & 37 & 6.5 & [23] \\
\hline S. cerevisiae CBS 1200 & 0.5 & $<1$ & 0.3 & 2 & 24 & 26 & 5.8 & [32] \\
\hline S. cerevisiae NSI 113 & 2 & nd & 0.3 & 1 & 48 & 30 & 5.3 & [33] \\
\hline Z. mobilis ATCC 10988 & 2 & 5 & 0.3 & 2 & 24 & 30 & 5.6 & [32] \\
\hline
\end{tabular}

* Concentration at which 50\% inhibition of growth occurred with furfural and 5-hydroxymethylfurfural (5-HMF). Values determined in this study are highlighted in boldface. " Medium also included $1 \%$ tryptone; ${ }^{\top}$ measured as $50 \%$ inhibition of ethanol production; $\mathrm{YE}$, yeast extract; nd, not determined; xyl, xylose; TS, This study. 

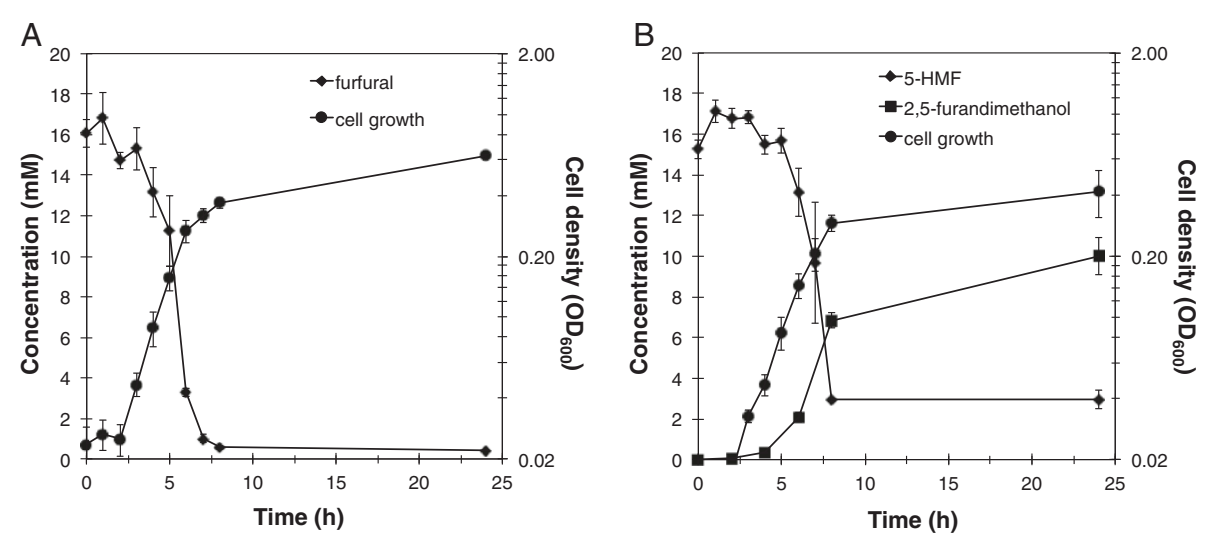

Figure 2 T. pseudethanolicus furan aldehyde reduction. T. pseudethanolicus was grown at $65^{\circ} \mathrm{C}$ with $40 \mathrm{mM}$ glucose and $15 \mathrm{mM}$ (A) furfural or (B) 5-HMF. Growth was measured by optical density at $600 \mathrm{~nm}$. Furan aldehyde concentration was measured spectrophotometrically, while furan alcohol concentration was measured by gas chromatography-mass spectrometry. Error bars are the standard deviation of three replicate cultures.

of one $\mathrm{NAD}(\mathrm{P}) \mathrm{H}$ per furan aldehyde and two $\mathrm{NAD}(\mathrm{P}) \mathrm{H}$ per ethanol. The reason for increased lactate with added furan aldehyde, especially 5-HMF, is less clear. Further redox imbalances from the presence of furfural or 5-HMF may direct more NADH generated from glycolysis to be oxidized via lactate dehydrogenase (LdhA). Furfural addition to a growing culture of the related thermophilic bacterium C. thermocellum also resulted in increased lactate production and cessation of ethanol production [37], although the reason for these changes is unknown. The mesophilic ethanologen $S$. cerevisiae has also been shown to remove furan aldehydes by reduction to their respective alcohols at the expense of ethanol production [38]. This has been shown to involve an upregulation of central carbon metabolism, especially the
NADPH-generating pentose phosphate pathway [39], and downregulation of enzymes involved in ethanol formation, thereby increasing the availability of reducing equivalents for aldehyde detoxification [40].

\section{Cell-wide proteomic response to furfural}

In order to identify potential enzymes involved in reducing furfural and 5-HMF and also to examine cell-wide physiological effects of furan aldehyde exposure, proteomic analysis was performed comparing T. pseudethanolicus $39 \mathrm{E}$ grown with and without furfural. A concentration of $15 \mathrm{mM}$ furfural was used to challenge the cells since this was the maximum amount that displayed a stimulatory effect during the growth experiments (Figure 1A). Triplicate

- glucose $\square$ lactate $\square$ acetate $\square$ ethanol
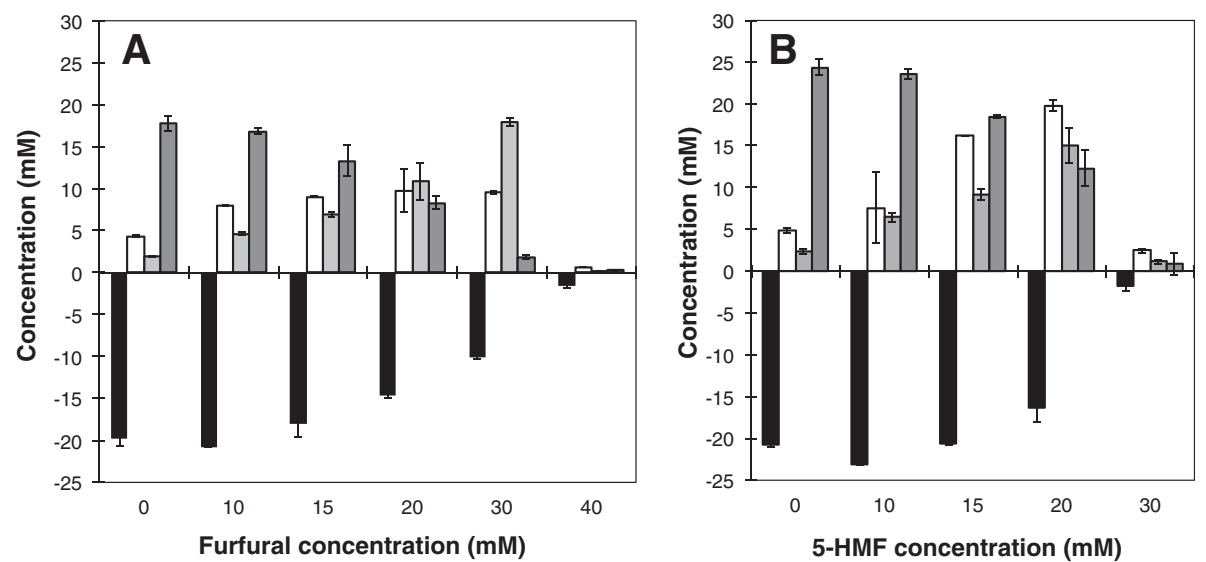

Figure 3 24-h substrate and end product analysis. T. pseudethanolicus was grown at $65^{\circ} \mathrm{C}$ with $40 \mathrm{mM}$ glucose and increasing concentrations of (A) furfural or (B) 5-HMF for 24 h. Culture supernatants were analyzed for glucose and end product formation by HPLC. Glucose consumption was determined by comparison with an uninoculated control. Error bars are the standard deviation of three replicate cultures. 


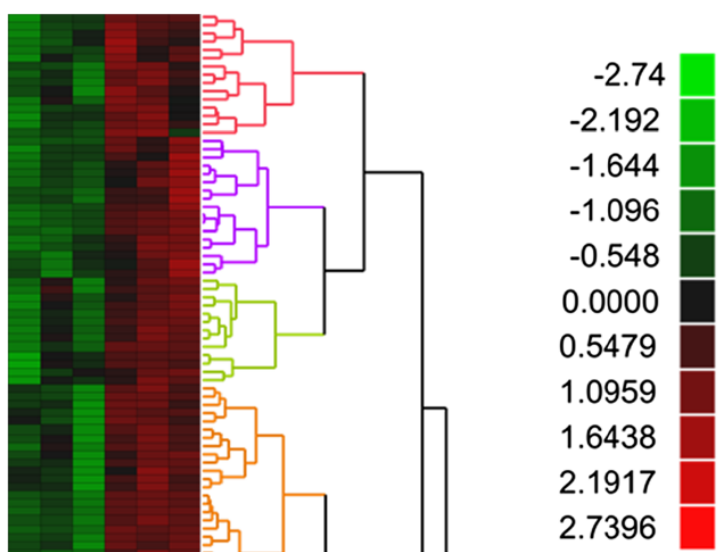


cultures were grown in parallel either in the presence or absence (control) of furfural and harvested at $8 \mathrm{~h}$ after inoculation, which corresponded to the time interval necessary for complete reduction of furfural to furfuryl alcohol (Figure 2A). Peptide samples were prepared and analyzed as described in the Methods section. The mass spectrometry proteomics data have been deposited to the ProteomeXchange Consortium [41] via the PRIDE partner repository with the dataset identifier PXD001446. The complete proteomics dataset and statistical analysis are also provided in Additional file 1: Table S1, which includes an in-table, color-coded heat map corresponding to Figure 4. In total, 1,294 proteins were identified across both conditions with roughly 300,000 spectra (SpC) assigned to constituent peptides. Of the 1,294 proteins, only 918 passed the $99 \% \mathrm{SpC}$ cutoff and were moved to the ANOVA analysis. Using a $P$-value cutoff of $0.05,225$ proteins were found to be differentially expressed with 152 upregulated in furfural treated cells versus 73 downregulated. Culling this list even further, only 87 proteins exhibited a twofold or greater change in abundance in either direction. Of these, 54 were upregulated in the presence of furfural (Table 2) and 33 were downregulated (Table 3). Significantly regulated proteins were grouped into 11 clusters based on abundance pattern across all replicates (Figure 4). Many cellular functions were affected by furfural, with the most highly downregulated proteins involved in cell wall biosynthesis or sporulation. Hydrogenase-related proteins were also downregulated, along with several redox proteins predicted to use $\mathrm{NAD}(\mathrm{P}) \mathrm{H}$. Upregulated proteins fell into 12 general cellular functions, with those regulated fivefold or higher falling into three categories: polar amino acid biosynthesis (arginine, cysteine), nucleotide metabolism, and redox proteins.

\section{Energy production and carbohydrate metabolism}

Comparatively, the proteomic response of T. pseudethanolicus $39 \mathrm{E}$ to furfural showed similarities at the functional level to the responses of $C$. thermocellum, as well as S. cerevisiae and E. coli. While central carbon metabolism did not appear to be significantly impacted by furfural in $T$. pseudethanolicus 39E, upregulated carbohydrate-related proteins included beta-galactosidase, mannose-6-phosphate isomerase, and kojibiose phosphorylase, while dihydroxyacetone kinase and two fructose-specific, phosphoenol -pyruvate-dependent sugar phosphotransferase system transport proteins were downregulated. Genes involved in energy production and conversion, as well as carbohydrate transport and metabolism, were also regulated in C. thermocellum ATCC 27405 [37]. Acetate kinase and phosphoacetyltransferase were both downregulated, though this is likely a general stress response rather than furfuralspecific. As in T. pseudethanolicus 39E, beta-galactosidase was upregulated in C. thermocellum ATCC 27405 upon furfural exposure, as were several glycosyl transferase family proteins, though the reason for this regulation is unclear. On the other hand, central carbon metabolism is significantly upregulated in both the $S$. cerevisiae and $E$. coli response to furfural. In anaerobic $S$. cerevisiae fermentations, an $8 \mathrm{~g} / \mathrm{L}$ furfural treatment repressed the synthesis of enzymes involved in glucose catabolism and the tricarboxylic acid (TCA) cycle. Conversely, addition of $17 \mathrm{~g} / \mathrm{L}$ furfural to an aerobic $S$. cerevisiae culture increased expression of proteins involved in glycolysis and the TCA cycle, while repressing expression of proteins involved in glycerol and ethanol production [42]. Analysis of a singlegene disruption library of $S$. cerevisiae BY4741 against growth with furfural identified several genes in the pentose phosphate pathway as important in furfural tolerance [39], especially $Z W F 1$, whose overexpression allowed for growth with $50 \mathrm{mM}$ furfural. In an ethanologenic strain of E. coli (LY180), a moderate furfural challenge $(0.5 \mathrm{~g} / \mathrm{L})$ perturbed the expression of about 400 genes at least twofold, 15 min after exposure, with central carbon and energy metabolism being among the pathways regulated [22]. It is interesting to note that central carbon metabolism is significantly regulated in the mesophilic $S$. cerevisiae and $E$. coli and is much less affected in the thermophilic C. thermocellum and T. pseudethanolicus, though the reason for this difference remains unclear.

\section{Stress response}

With $15 \mathrm{mM}$ furfural, T. pseudethanolicus 39E did not display a typical stress phenotype indicated by a reduced growth rate. Nevertheless, some functions associated with stress were differentially regulated. The expression of eight predicted transporters was affected by furfural, including upregulation of three metal transporters and one efflux transporter. A variety of nucleotide-related genes were also upregulated, including two de novo purine biosynthesis genes (Teth39_1713 and Teth39_1803) and two genes involved in nucleoside degradation (Teth39_1828 and Teth39_1832). Additionally, Teth39_1216, predicted to be involved in isoprenoid biosynthesis, and Teth39_0175, predicted to function in cell wall turnover, are downregulated in response to furfural. Similarly, a number of stress 
Table 2 Proteins upregulated twofold or more by $15 \mathrm{mM}$ furfural $(P \leq 0.05)$

\begin{tabular}{|c|c|c|}
\hline Locus & $\begin{array}{l}\text { Fold } \\
\text { change }\end{array}$ & Description \\
\hline \multicolumn{3}{|c|}{ Amino acid biosynthesis } \\
\hline Teth39_0141 & 2.22 & Threonine synthase \\
\hline Teth39_0223 & 4.31 & $\begin{array}{l}\mathrm{N} \text {-acetyl-gamma-glutamyl-phosphate } \\
\text { reductase }\end{array}$ \\
\hline Teth39_0224 & 6.61 & $\begin{array}{l}\text { Arginine biosynthesis bifunctional } \\
\text { protein ArgJ }\end{array}$ \\
\hline Teth39_0225 & 2.50 & Acetylglutamate kinase \\
\hline Teth39_0226 & 2.65 & $\begin{array}{l}\text { Acetylornithine and succinylornithine } \\
\text { aminotransferase }\end{array}$ \\
\hline Teth39_0227 & 7.69 & $\begin{array}{l}\text { Carbamoyl phosphate synthase, } \\
\text { small subunit }\end{array}$ \\
\hline Teth39_0228 & 12.73 & $\begin{array}{l}\text { Carbamoyl phosphate synthase, } \\
\text { large subunit }\end{array}$ \\
\hline Teth39_0229 & 5.74 & Argininosuccinate synthase \\
\hline Teth39_0279 & 3.50 & Cysteine synthase A \\
\hline Teth39_0280 & 6.68 & Cysteine desulfurase \\
\hline Teth39_0281 & 9.01 & tRNA methyltransferase \\
\hline Teth39_0559 & 2.56 & Diaminopimelate decarboxylase \\
\hline Teth39_0983 & 3.14 & Prephenate dehydratase \\
\hline Teth39_1666 & 2.17 & Glutamine synthetase, catalytic region \\
\hline Teth39_1810 & 3.56 & Aspartate 1-decarboxylase \\
\hline \multicolumn{3}{|c|}{ Carbohydrate metabolism } \\
\hline Teth39_0611 & 2.28 & Beta-galactosidase \\
\hline Teth39_0744 & 2.26 & $\begin{array}{l}\text { Mannose-6-phosphate isomerase, class } \\
\text { I }\end{array}$ \\
\hline Teth39_1512 & 3.34 & Kojibiose phosphorylase \\
\hline
\end{tabular}

Cell division/sporulation/motility

$\begin{array}{lll}\text { Teth39_1000 } & 2.05 & \text { SpollD/LytB domain } \\ \text { Teth39_1257 } & 4.17 & \text { Flagellar M-ring protein FliF } \\ \text { Teth39_1280 } & 2.08 & \text { Chromosome segregation protein SMC }\end{array}$ value 0.015 0.001

0.000 0.010

0.038

0.010

0.008

0.008

0.000

0.001

0.001

0.014

0.001

0.002

0.003

0.033

0.011

0.034

0.043

009

0.043

Chaperones

Teth39_0115 2.15

Chaperonin Cpn10

Teth39_1392 2.21

Chaperone protein DnaJ

\section{Energy related}

$\begin{array}{lll}\text { Teth39_1820 } & 2.04 & \text { Homocitrate synthase } \\ \text { Teth39_2064 } & 6.75 & \begin{array}{l}\text { 2-hydroxyacid dehydrogenase, } \\ \text { NAD-binding }\end{array}\end{array}$

Hypothetical proteins

$\begin{array}{lll}\text { Teth39_0463 } & 2.28 & \text { Hypothetical protein } \\ \text { Teth39_0919 } & 2.78 & \text { Hypothetical protein }\end{array}$

\section{Iron-sulfur cluster metabolism}

$\begin{array}{lll}\text { Teth39_0116 } & 2.14 & \text { FeS assembly ATPase SufC } \\ \text { Teth39_0117 } & 2.65 & \text { FeS assembly protein SufB } \\ \text { Teth39_0118 } & 2.97 & \text { SufBD protein }\end{array}$

Teth39_0118 2.97 SufBD protein

0.013

0.005

0.003

0.019

Table 2 Proteins upregulated twofold or more by $15 \mathrm{mM}$ furfural $(\boldsymbol{P} \leq \mathbf{0 . 0 5})$ (Continued)

\begin{tabular}{llll}
\hline Teth39_0120 2.66 SUF system FeS assembly protein, & 0.001
\end{tabular} NifU family

Nucleotide related

Teth39 $0775 \quad 2.04$

MutS2 family protein

0.005

Teth39_1049 2.07

tRNA methyltransferase

0.018

Teth39_1323 2.46

DNA-directed RNA polymerase,

0.005

Teth39_1713 2.12 Phosphoribosylformylglycinamidine 0.006 synthase II

Teth39 1803 36.39 Phosphoribosylaminoimidazole carboxylase, ATPase subunit

0.000

Teth39_1828 2.76

Cytidine deaminase

0.009

Teth39_1832 2.14

$\mathrm{ABC}$ transporter related

0.004

Redox proteins

Teth39_0646 3.61

FAD-dependent pyridine nucleotide

0.005

Teth39_0720 3.77 disulfide oxidoreductase

4Fe-4S ferredoxin, iron-sulfur binding $\quad 0.044$ domain protein

Teth39_1597 $6.84 \quad$ Iron-containing alcohol

dehydrogenase

Teth39_1598 6.32

Aldo/keto reductase

0.000

Ribosomal proteins

Teth39_0365 2.00

Ribosomal protein L7/L12

0.020

Teth39_1753 2.01

RNA binding S1 domain protein

0.001

Teth39_2275 2.33

Ribosomal protein $\mathrm{S} 6$

0.006

Transporters

Teth39_0231 2.85

Calcium translocating P-type ATPase,

0.001

PMCA-type

Teth39_0278 2.82

Heavy metal translocating P-type

0.036

ATPase

Teth39_0282 4.65

Copper translocating P-type ATPase

0.004

Teth39_1033 2.26

Efflux transporter, RND family,

0.015 MFP subunit

Teth39_1765 4.62

Extracellular solute-binding protein,

0.001 family 3

Teth39_2232 2.43

Type IV secretory pathway VirB4

0.011

\section{Vitamin related}

Teth39_0307 3.10

Biotin/lipoyl attachment domain-containing protein

Teth39_1205 2.03 Riboflavin biosynthesis protein RibF 0.001

Teth39_1559 2.00 SNO glutamine amidotransferase

0.001

0.012

0.023

Sorted by general cellular function. Proteins in boldface are regulated greater than fivefold. Descriptions are from the National Center for Biotechnology Information.

0.020

0.001

0.000 responses are upregulated by furfural in C. thermocellum ATCC 27405, including many genes that are homologous to class I and class IV heat shock response genes in Bacillus subtilis, though these genes were also upregulated by heat [37] and ethanol treatment [43]. A number of 
Table 3 Proteins downregulated twofold or more by $15 \mathrm{mM}$ furfural $(P \leq 0.05)$

\begin{tabular}{llll}
\hline Locus & $\begin{array}{l}\text { Fold } \\
\text { change }\end{array}$ & Description & $\begin{array}{l}\boldsymbol{P} \text { - } \\
\text { valu }\end{array}$ \\
\hline Amino acid metabolism & \\
Teth39_0216 & -3.10 & $\begin{array}{l}\text { Glutamate synthase, homotetrameric } \\
\text { Oxidoreductase FAD/NAD(P)-binding }\end{array}$ & 0.000 \\
Teth39_0217 & -2.47 & $\begin{array}{l}\text { Oomain } \\
\text { don }\end{array}$ & 0.038 \\
Teth39_0487 & -2.15 & Alanine racemase \\
Teth39_1661 & -3.77 & $\begin{array}{l}\text { Glutamine amidotransferase, class II } \\
0.016\end{array}$ \\
Teth39_2007 & -2.58 & $\begin{array}{l}\text { Aromatic amino acid beta-eliminating } \\
\text { lyase }\end{array}$ & 0.004
\end{tabular}

Cell division/sporulation/motility

Teth39 $0175 \quad-52.70$

Teth39_0252 -30.04

Teth39_1446 -2.42

Peptidoglycan-binding LysM

0.000

0.000

0.016

Cell division topological specificity factor MinE

Teth39_1772 -2.33

Flagellar protein FlaG protein

0.011

Teth39_1783 -2.51 Flagellar hook-associated protein 3

\section{Energy related}

Teth39_0466 -2.27

Thiamine pyrophosphate enzyme domain

Hydrogenase related

Teth39_0221 -2.17

Teth39_1458 -2.05

Hydrogenase with PAS/PAC sensor

Hypothetical protein

Teth39_1459 -24.50

Hypothetical proteins

Teth39 $0794-5.93$

Teth39_0842 -36.68

Nucleotide related

Teth39_1357 -2.51

Metal-dependent phosphohydrolase

Teth39 $2157 \quad-9.29$

SirA family protein

Redox proteins

Teth39_0445 - -2.19

Teth39_1916 -2.73

Thioredoxin reductase

Oxidoreductase FAD/NAD(P)-binding domain

Teth39_1917 -4.88 4Fe-4S ferredoxin, iron-sulfur binding domain

Teth39_2155 -4.30 FAD-dependent pyridine nucleotidedisulfide oxidoreductase

Transcriptional regulator

\begin{tabular}{|c|c|c|}
\hline Teth39_0150 & -2.56 & Transcriptional regulator, DeoR family \\
\hline Teth39_0757 & -3.07 & $\begin{array}{l}\text { Putative cold-shock DNA-binding } \\
\text { domain protein }\end{array}$ \\
\hline Teth39_1109 & -2.27 & $\begin{array}{l}\text { Sporulation transcriptional activator } \\
\text { SpoOA }\end{array}$ \\
\hline Teth39_1292 & -2.06 & Hypothetical protein \\
\hline Teth39_1796 & -2.17 & $\begin{array}{l}\text { Two-component transcriptional } \\
\text { regulator, winged helix family }\end{array}$ \\
\hline
\end{tabular}

Table 3 Proteins downregulated twofold or more by $15 \mathrm{mM}$ furfural $(P \leq \mathbf{0 . 0 5})$ (Continued)

\begin{tabular}{|c|c|c|c|}
\hline \multicolumn{4}{|l|}{ Transporters } \\
\hline Teth39_0333 & -2.98 & $\begin{array}{l}\text { PTS system, fructose subfamily, } \\
\text { IC subunit }\end{array}$ & 0.001 \\
\hline Teth39_0334 & -2.90 & $\begin{array}{l}\text { PTS system, fructose-specific, } \\
\text { IB subunit }\end{array}$ & 0.019 \\
\hline \multicolumn{4}{|c|}{ Vitamin related } \\
\hline Teth39_0787 & -4.71 & Lipoic acid synthetase & 0.033 \\
\hline \multicolumn{4}{|l|}{ Other } \\
\hline Teth39_0542 & -2.43 & $\begin{array}{l}\text { Dihydroxyacetone kinase, } \\
\text { DhaK subunit }\end{array}$ & 0.006 \\
\hline Teth39_1065 & -2.21 & $\begin{array}{l}\text { HAD superfamily (subfamily IIIA) } \\
\text { phosphatase, TIGR01668 }\end{array}$ & 0.024 \\
\hline Teth39_1216 & -2.04 & $\begin{array}{l}\text { 1-hydroxy-2-methyl-2-(E)-butenyl } \\
\text { 4-diphosphate synthase }\end{array}$ & 0.011 \\
\hline
\end{tabular}

Sorted by general cellular function. Proteins in boldface are regulated greater than fivefold. Descriptions are from the National Center for Biotechnology Information.

uncharacterized transporters were also regulated, as well as genes involved in transcription, RNA processing and modification, chromatin structure and dynamics, and DNA replication, recombination, and repair. In S. cerevisiae, stress responses upregulated by furfural include osmotic and salt stress, DNA damage, and $\mathrm{pH}$ stress [40]. $S$. cerevisiae also responds to furan aldehydes by regulating cell adaptation and survival processes, especially with respect to drug resistance, transport, and cell membrane composition [38]. In E. coli LY180, transport functions, as well as cell structure, DNA, and lipid synthesis functions are also regulated by furfural [22]. A general stress response to furfural thus appears to include upregulation of transport functions and nucleotide metabolism.

\section{Amino acid metabolism}

In T. pseudethanolicus 39E grown with $15 \mathrm{mM}$ furfural, both cysteine and arginine biosynthetic genes were upregulated (cysteine synthase A, Teth39_0279; cysteine desulfurase, Teth39_0280; arginine biosynthesis, Teth39_02230229). Amino acid metabolism is also affected by furfural stress in C. thermocellum, S. cerevisiae, and E. coli. In $C$. thermocellum ATCC 27405, arginine biosynthetic genes are upregulated upon furfural addition [37]. While sulfur amino acid biosynthesis is not directly regulated, genes involved in sulfate transport and sulfur assimilation are upregulated by furfural. In S. cerevisiae, proteins involved in sulfur amino acid biosynthesis are downregulated upon exposure to $8 \mathrm{~g} / \mathrm{L}$ furfural under anaerobic conditions [40]. In E. coli LY180, $0.5 \mathrm{~g} / \mathrm{L}$ furfural also repressed genes involved in arginine biosynthesis, but induced expression of sulfur-containing amino acid biosynthetic genes [22]. This is due to a decrease in NADPH availability, which is instead used by the aldehyde reductases YqhD and DkgA 
for furfural reduction [22]. Upregulation of cysteine biosynthetic pathways in T. pseudethanolicus 39E suggests that, as in $E$. coli, increased expression of $\mathrm{NAD}(\mathrm{P}) \mathrm{H}-$ dependent aldehyde reductases (described below) may decrease NADPH availability for sulfur amino acid biosynthesis.

\section{Redox metabolism}

Six alcohol dehydrogenases (ADHs) identified in $T$. pseudethanolicus 39E were differentially regulated. The three functionally characterized ADHs [36,44], AdhA (Teth39_0220), AdhB (Teth39_0218), and AdhE (Teth39_0206), were all downregulated $(P<0.05)$; however, none more than twofold (AdhA 1.27-fold, AdhB 1.81-fold, and AdhE 1.59-fold). Of the other three identified alcohol dehydrogenases in T. pseudethanolicus 39E (Teth39_0878, Teth39_1597, Teth39_1979), only Teth39_1597 was significantly upregulated (6.8-fold; $P$ $<0.001)$. Another oxidoreductase upregulated by T. pseudethanolicus 39E in response to furfural is Teth39_1598 (6.3-fold; $P<0.001)$. These genes potentially encode enzymes involved in reducing furfural and 5-HMF and will be discussed in more detail below. In $C$. thermocellum ATCC 27405, the bifunctional alcohol/aldehyde dehydrogenase Cthe_0423 and the redox regulator Rex (Cthe_0422) were downregulated upon furfural addition [37]. No other alcohol dehydrogenase or aldehyde reductase was differentially regulated; however, a putative carbon monoxide dehydrogenase (Cthe_0281) was upregulated by furfural and may play a role in redox balance in $C$. thermocellum ATCC 27405 [37]. In $S$. cerevisiae, $\mathrm{NAD}(\mathrm{P}) \mathrm{H}$-dependent aldehyde reductases or alcohol dehydrogenases (ADH) have also been shown to affect furan aldehyde tolerance [45] and be regulated by furan aldehydes [40]. Transcriptomic expression analysis of known reductase and dehydrogenase genes showed that $A D H 2$ was highly expressed in hydrolysate-tolerant S. cerevisiae strain TMB3000 compared to the wild-type CBS8066 and was also induced by 5-HMF [45]. In a proteomic analysis of the response of $S$. cerevisiae to $17 \mathrm{~g} / \mathrm{L}$ furfural, six ADHs showed differential regulation, with Adh1p, Adh5p, and Adh6p upregulated, Adh2p and Sfa1p downregulated, and Adh4p unregulated by furfural [42]. Adh6p and Adh7p have furfural and 5-HMF reductase activity, with the former using both NADH and $\mathrm{NADPH}$ and the latter only NADH [46]. In E. coli LY180, energy functional groups are also highly regulated [22]. As in S. cerevisiae, NADPH-dependent aldehyde reductases with furfural reducing capacity are upregulated, namely $y q h D$ and $d k g A$.

\section{Enzyme cloning and activity measurements}

Teth39_1597 [GenBank GeneID:5874751] shares 36\% identity $/ 54 \%$ similarity with $y q h D$ from E. coli LY180
[22]. Teth39_1597 belongs to the Fe-dependent alcohol dehydrogenase superfamily (pfam00465) with predicted butanol dehydrogenase activity (BDH, cd08187). The gene product appears to be a close homolog of BdhA in Thermoanaerobacter mathranii (88\% identity/94\% similarity), which has been experimentally verified to have BDH activity [47]. Thus, Teth39_1597 is considered to be a butanol dehydrogenase and will be referred to as Teth39 bdhA. Teth39_1598 [GenBank GeneID:5874752] has $27 \%$ identity $/ 41 \%$ similarity to $d k g A$ from $E$. coli LY180, another enzyme shown to have NADPHdependent furfural reductase activity [22]. Teth39_1598 is a predicted aldo/keto oxidoreductase and will be referred to as Teth39 akr.

Since both Teth39 $b d h A$ and Teth39 $a k r$ were significantly upregulated in response to furfural and are homologs to similarly upregulated $E$. coli genes $y q h D$ and $d k g A$, further biochemical characterization was performed to determine their cofactor and substrate specificities. The coding regions for Teth39 $b d h A$ and Teth39 akr were PCR amplified from T. pseudethanolicus 39E genomic DNA and cloned into pET-30a behind a T7-lac promoter and N-terminal 6xHis- and S-tags. Overexpression plasmids, as well as the pET-30a plasmid alone, were transformed into E. coli BL21 (DE3) and Teth39 BdhA and Teth39 AKR were overexpressed (Figure 5). Whole cell lysates were prepared and assayed for aldehyde reductase activity aerobically at $60^{\circ} \mathrm{C}$ with acetaldehyde, furfural, and 5-HMF. Furfural was also assayed under anaerobic conditions. Teth39 BdhA and Teth39 AKR activities were compared to the vector-only control (Table 4). Neither enzyme showed any activity with NADH as cofactor. Teth39 AKR had minimal activity with both furan aldehydes using NADPH as the cofactor, but not above the vector control. In contrast, Teth39 BdhA showed activity above the vector control using NADPH as the cofactor with both furan aldehydes. The specific activity was $4.97 \pm 0.17 \mathrm{U}$ with furfural and $10.06 \pm 0.80$ $\mathrm{U}$ with 5-HMF.

Based on these results, overexpression of Teth39 bdhA may increase microbial tolerance to the furan aldehydes furfural and 5-HMF produced during biomass pretreatment, especially in a thermophilic, cellulolytic microbe, such as a Caldicellulosiruptor sp. or Clostridium thermocellum. This approach has proven successful in S. cerevisiae, where overexpression of $A D H 6$ or $A D H 7$ allowed growth with $40 \mathrm{mM} 5$-HMF, where none was seen in a control [46]. However, the increased expression of Teth39 $b d h A$ in T. pseudethanolicus 39E may have influenced other aspects of its furfural proteomic response. For example, Teth39 BdhA is predicted to contain iron-sulfur clusters, and ironsulfur cluster biosynthetic genes (Teth39_0116-0120) are also upregulated by furfural. Additionally, other oxidoreductases predicted to use NADPH as a cofactor are 


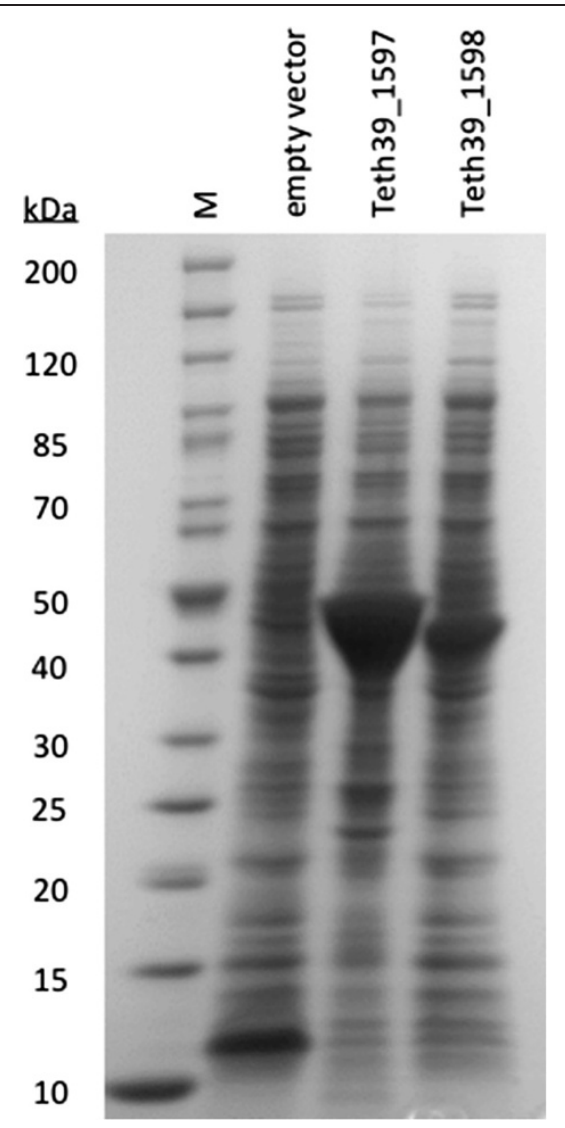

Figure 5 Overexpression of Teth39_1597 and Teth39_1598 in Escherichia coli. Teth39_1597 (48.4 kDa) and Teth39_1598 (42.1 kDa) were cloned from T. pseudethanolicus into pET-30a and overexpressed from a T7 promoter after induction with IPTG. Overexpression was determined in whole cell extract by Coomassie-stained SDS-PAGE.

downregulated (Teth39_0216, Teth39_0217, Teth39_1916), perhaps to increase NADPH availability for furfural reduction. Thus, while overexpression of Teth 39 BdhA alone may increase furan aldehyde tolerance, coexpression of other genes may be required to achieve the phenotype overall.

Teth39 BdhA and Teth39 AKR also exhibited butyraldehyde and isobutyraldehyde reduction activity (Table 4), presumably forming butanol and isobutanol, with the Teth39 BdhA activity 2.7-fold higher than that of Teth39 AKR with isobutyraldehyde and 44.2-fold higher with butyraldehyde. Expression of Teth39 bdhA might therefore alternatively be used to biologically produce these higher energy fuel compounds in thermophilic microbes.

\section{Conclusions}

Inhibitors, such as furfural and 5-HMF, are generated from common pretreatment methods used for improving the reactivity of lignocellulosic biomass toward enzymatic solubilization. The physiological response and tolerance to these inhibitors must be understood in order to develop
Table 4 Specific activity ( $\mu \mathrm{mol} / \mathrm{min} / \mathrm{mg}$ protein) of putative T. pseudethanolicus $39 \mathrm{E}$ aldehyde reductases

\begin{tabular}{llll}
\hline & Vector control & Teth39 BdhA & Teth39 AKR \\
\hline Furfural & $0.33 \pm 0.13$ & $\mathbf{4 . 9 7} \pm \mathbf{0 . 1 7}$ & $0.27 \pm 0.04$ \\
5-Hydroxymethylfurfural & $0.44 \pm 0.16$ & $\mathbf{1 0 . 0 6} \pm \mathbf{0 . 8 0}$ & $0.39 \pm 0.07$ \\
Acetaldehyde & $0.02 \pm 0.15$ & $\mathbf{4 . 5 4} \pm \mathbf{0 . 7 6}$ & $0.02 \pm 0.01$ \\
Butyraldehyde & $0.09 \pm 0.05$ & $\mathbf{1 4 . 5 8} \pm \mathbf{3 . 5 7}$ & $\mathbf{0 . 3 3} \pm \mathbf{0 . 0 4}$ \\
Isobutyraldehyde & $-0.10 \pm 0.21$ & $\mathbf{0 . 6 3} \pm \mathbf{0 . 2 9}$ & $\mathbf{0 . 2 3} \pm \mathbf{0 . 0 5}$ \\
\hline
\end{tabular}

Whole cell lysate with pET-30a only (vector control) or expressing Teth39 BdhA (Teth39_1597) or Teth39 AKR (Teth39_1598) was assayed aerobically at $60^{\circ} \mathrm{C}$ using $0.2 \mathrm{mM} \mathrm{NAD}(\mathrm{P}) \mathrm{H}$ as the electron donor and $20 \mathrm{mM}$ substrate. NAD(P)H oxidation activity was measured via loss of absorbance at $340 \mathrm{~nm}$. Values in boldface are statistically significant. No activity was detected with either Teth39 BdhA or Teth39 AKR above vector control using NADH.

improved microorganisms such as C. thermocellum or a Caldicellulosiruptor sp. for thermophilic consolidated bioprocessing of biomass. We measured rapid growth in the presence of 10 to $15 \mathrm{mM}$ furan aldehydes and their detoxification in situ by a thermophilic anaerobe, $T$. pseudethanolicus 39E. Physiological effects resulting from higher furfural and 5-HMF concentrations included decreased ethanol yield with increases in acetate and lactate production from glucose. A bottom-up proteomics approach was applied to screen for potential enzymes or pathways directly involved in furan aldehyde detoxification. While a number of cellular functions were impacted, including a decrease in expression of ADHs involved in ethanol production, an ADH encoded by Teth39_1597 was upregulated nearly sevenfold in the presence of $15 \mathrm{mM}$ furfural. The enzyme, a putative butanol dehydrogenase, was cloned and overexpressed in E. coli and displayed NADPH-dependent activity against furfural and 5-HMF, suggesting a direct role in detoxifying furan aldehyde inhibitors in situ.

\section{Methods}

\section{Growth experiments}

Thermoanaerobacter pseudethanolicus 39E (DSMZ 2355) was purchased from Deutsche Sammlung von Mikroorganismen und Zellkulturen GmbH (DSMZ, Braunschweig, Germany). All chemicals were purchased from SigmaAldrich (St. Louis, MO) unless otherwise indicated. The anaerobic growth medium was prepared using a modified Hungate technique [48] and consisted of $4.5 \mathrm{mM} \mathrm{KCl}$, $4.7 \mathrm{mM} \mathrm{NH}_{4} \mathrm{Cl}, 2.5 \mathrm{mM} \mathrm{MgSO} 4 \cdot 7 \mathrm{H}_{2} \mathrm{O}, 1.0 \mathrm{mM} \mathrm{NaCl}$, $0.7 \mathrm{mM} \mathrm{CaCl} 2 \cdot 2 \mathrm{H}_{2} \mathrm{O}, 0.25 \mathrm{mg} / \mathrm{mL}$ resazurin, $2.8 \mathrm{mM}$ cysteine- $\mathrm{HCl}, 6.0 \mathrm{mM} \mathrm{NaHCO} 3,1 \mathrm{mM}$ potassium phosphate buffer (pH 6.8), $10 \mathrm{mM} 3-(\mathrm{N}$-morpholino)propanesulfonic acid ( $\mathrm{pH}$ 6.8), 1x Wolfe's trace minerals [49], $1 \times$ Wolfe's vitamin supplement [49], 0.1\% (w/v) yeast extract (Fisher Scientific, Pittsburgh, PA), and $40 \mathrm{mM}$ glucose. Furan aldehydes were added from degassed concentrated stock solutions. Cultures were grown at $65^{\circ} \mathrm{C}$ from a $1 \%$ inoculum in Balch tubes $(10 \mathrm{~mL})$ or $125-\mathrm{mL}$ serum bottles 
$(50 \mathrm{~mL})$. Cell growth was monitored by optical density at $600 \mathrm{~nm}$, either directly in the Balch tube using a Spectronic 200 spectrophotometer (Thermo Fisher Scientific, Waltham, MA) or as $200-\mu \mathrm{L}$ samples transferred to a 96-well plate and read on a Synergy Mx plate reader (BioTek, Winooski, VT). All growth experiments were performed in triplicate.

\section{Small molecule measurement}

Glucose, lactate, acetate, and ethanol were measured via HPLC as previously described using an HPX-87H column (Bio-Rad Laboratories, Hercules, CA) at $60^{\circ} \mathrm{C}$ with detection via refractive index and $5 \mathrm{mM} \mathrm{H}_{2} \mathrm{SO}_{4}$ as the mobile phase [50]. Furfural and 5-HMF were measured spectrophotometrically (DU 800, Beckman Coulter, Brea, CA) at 304 and $323 \mathrm{~nm}$, respectively, and concentrations were determined using standard curves generated in growth medium. 2,5-furandimethanol was measured using gas chromatography-mass spectrometry (GC-MS) following trimethylsilylation, with an Agilent 5975C standard quadrupole GC-MS using electron impact ionization $(970 \mathrm{eV})$, as described previously [51].

\section{Proteomic analysis: sample preparation}

Cell pellets (10 to $50 \mathrm{mg}$ ) from cultures grown for $8 \mathrm{~h}$ (early stationary phase) with and without $15 \mathrm{mM}$ furfural were frozen at $-80^{\circ} \mathrm{C}$ prior to preparation. The thawed pellets were resuspended in $1 \mathrm{~mL}$ lysis buffer (4\% SDS, $100 \mathrm{mM}$ Tris- $\mathrm{HCl} \mathrm{pH} \mathrm{8.0,} 50 \mathrm{mM}$ dithiothreitol) and boiled for $5 \mathrm{~min}$. Samples were then pulse-sonicated $(10 \mathrm{~s}$ on, $10 \mathrm{~s}$ off) for $2 \mathrm{~min}$ with an ultrasonic disruptor (Branson, Danbury, CT) at 20\% amplitude. The samples were boiled again for $5 \mathrm{~min}$, cleared by centrifugation $(21,000 \times g$, $10 \mathrm{~min}, \mathrm{RT})$, and immediately precipitated with $20 \%$ trichloroacetic acid overnight at $-20^{\circ} \mathrm{C}$. Precipitated proteins were washed twice with ice-cold acetone, air dried, and resuspended in $8 \mathrm{M}$ urea in $100 \mathrm{mM}$ Tris- $\mathrm{HCl}, \mathrm{pH}$ 8.0. The samples were sonicated as before and incubated for $30 \mathrm{~min}$ at room temperature (RT). Samples were adjusted to $10 \mathrm{mM}$ dithiothreitol (10 min, RT) and then $10 \mathrm{mM}$ iodoacetamide (10 min, RT, in the dark) to both reduce and block cysteine residues. Sample aliquots containing about $1.5 \mathrm{mg}$ of crude protein were diluted 1:1 (v/v) with $100 \mathrm{mM}$ Tris- $\mathrm{HCl}, \mathrm{pH} 8.0$ and $20 \mathrm{mM} \mathrm{CaCl}_{2}$ and digested with sequencing-grade trypsin (Promega, San Luis Obispo, $\mathrm{CA})$ at a 1:75 (w/w) enzyme:protein ratio (16 h, RT). The samples were again diluted $1: 1(\mathrm{v} / \mathrm{v})$ and digested with a second aliquot of trypsin $(1: 75 ; \mathrm{w} / \mathrm{w})$ for an additional $4 \mathrm{~h}$. Following digestion, each sample was adjusted to $200 \mathrm{mM}$ $\mathrm{NaCl}$ and $0.1 \%$ formic acid and filtered through a $10-\mathrm{kDa}$ cutoff spin column filter (Vivaspin 2, GE Healthcare, Pittsburgh, PA). The peptide-enriched flow-through was then quantified by the bicinchoninic acid assay.

\section{Proteomic analysis: measurement of peptides by two-dimensional liquid chromatography-tandem mass spectrometry (LC-MS/MS)}

For each sample, $100 \mu \mathrm{g}$ of peptides were bomb-loaded onto a biphasic MudPIT back column [52] packed with about $5 \mathrm{~cm}$ of strong cation exchange (SCX) resin for charge-based separation of peptides followed by about $3 \mathrm{~cm} \mathrm{C18}$ reversed phase (RP) for online desalting (Luna and Aqua respectively, Phenomenex, Torrance, CA). Once loaded, the sample columns were washed offline with solvent A (5\% acetonitrile, 95\% HPLC-grade water, 0.1\% formic acid) for $15 \mathrm{~min}$, followed by a gradient to $100 \%$ solvent B (70\% acetonitrile, 30\% HPLC-grade water, 0.1\% formic acid) over $30 \mathrm{~min}$. The washed samples were then placed in-line with an in-house pulled nanospray emitter (100- $\mu \mathrm{m}$ inner diameter) packed with $15 \mathrm{~cm}$ of C18 RP material and analyzed via 24-h MudPIT two-dimensional LC-MS/MS (eleven salt pulses: 5, 7.5, 10, 12.5, 15, 17.5, $20,25,35,50,100 \%$ of $500 \mathrm{mM}$ ammonium acetate followed by a $100-$ min gradient to $50 \%$ solvent B) with an LTQ XL mass spectrometer (Thermo Fisher Scientific) operating in data-dependent mode. A total of three biological replicate measurements were obtained for each sample.

\section{Proteomic analysis: MS data analysis and evaluation}

Acquired MS/MS spectra were assigned to specific peptide sequences using the SEQUEST search algorithm [53] with a FASTA proteome database specific to T. pseudethanolicus. The database contained common contaminant protein entries as well as reversed decoy sequences to assess protein-level false discovery rates. SEQUEST-scored peptide sequence data were filtered and assembled into protein loci using DTASelect [54] with the following conservative criteria: XCorr: $+1=1.8,+2=2.5,+3=3.5$, DeltCN 0.08 , and two peptides per protein identification with at least one required to be unique.

Prior to the semiquantitative analysis, spectral counts were rebalanced to properly distribute non-unique/ shared peptides between their potential parent proteins, as previously described [55]. To represent proteins that were sporadically identified across runs (that is, blank/zero values in a portion of the six sample runs), a fraction of a spectral count (0.33) was added to the entire dataset. This distributional shift maintains the originally measured spectral count differential but allows for blank/zero values to be considered in the ensuing statistical analysis [56]. These adjusted values were then converted to normalized spectral counts ( $\mathrm{nSpC}$ ), an extension of the widely recognized normalized spectral abundance factor (NSAF) [57] that is calculated by multiplying the NSAF values by an arbitrary number representative of the number of spectra collected for each run. In this case, the number 50,000 was used for facile data interpretation. Once calculated, an $\mathrm{SpC}$ cutoff was applied to all proteins identified in the 
dataset so that $99 \%$ of the total raw $\mathrm{SpC}$ assigned to each (summed across all replicates and conditions) remained.

These remaining proteins were $\log 2$ transformed, and statistically assessed by ANOVA with JMP Genomics ver. 4.1 (SAS Institute, Cary, NC) to identify proteins in the furfural treated samples that were significantly $(P \leq 0.05)$ up- or downregulated relative to the control. These differentially expressed proteins were then hierarchically clustered based on their abundance patterns across all replicates and conditions using the "Fast Ward" algorithm. To remove differences based on raw magnitude differences in $\mathrm{nSpC}$, each protein's abundance was standardized to represent the number of standard deviations away from the row mean.

\section{Aldehyde reductase cloning and overexpression}

T. pseudethanolicus genomic DNA was isolated using the Wizard Genomic DNA Purification kit (Promega, Madison, WI). Teth39_1597 and Teth39_1598 were PCR amplified using Phusion Polymerase (New England Biolabs, Ipswich, MA), cloned into pET-30a (EMD Millipore, Billerica, MA) behind 6xHis- and S-tags, and the final constructs were sequence verified (University of Tennessee, Knoxville, Molecular Biology Resource Facility). Expression plasmids were transformed in BL21 (DE3) Escherichia coli according to the manufacturer's protocol (Invitrogen, Grand Island, NY). Cells were grown in $50 \mathrm{~mL} 2 \times \mathrm{YT}$ medium at $37^{\circ} \mathrm{C}$ to $\mathrm{OD}_{600}$ of $0.8-1.0$, then induced with $100 \mu \mathrm{M}$ isopropyl- $\beta$-D-thiogalactopyranoside (IPTG) and switched to $30^{\circ} \mathrm{C}$ for $16 \mathrm{~h}$. Cells were harvested at $4^{\circ} \mathrm{C}$ $(3,000 \times g, 30 \mathrm{~min})$, washed in $50 \mathrm{~mL} 100 \mathrm{mM}$ sodium phosphate buffer, $\mathrm{pH} 7$ (buffer $\mathrm{A}$ ), and resuspended in $5 \mathrm{~mL}$ buffer $\mathrm{A}$. The cell suspension $(450 \mu \mathrm{L})$ was added to $0.1 \mathrm{~mm}$ zirconia beads $(300 \mu \mathrm{L})$ and vortexed $4 \times 60 \mathrm{~s}$ with $30 \mathrm{~s}$ on ice in between. The samples were centrifuged $(14,000 \times g, 2 \mathrm{~min})$, and the resulting supernatant was used for enzyme assays.

\section{Enyzme assays}

The in vitro aldehyde reductase activity was measured as previously described [23] in $100 \mathrm{mM}$ sodium phosphate buffer ( $\mathrm{pH} 7$ ) with $0.2 \mathrm{mM} \mathrm{NAD(P)H}$ and $20 \mathrm{mM}$ substrate. The assay mix was added to a sealed $2-\mathrm{mL}$ quartz cuvette and equilibrated to $60^{\circ} \mathrm{C}$. Assays were read at $340 \mathrm{~nm}$ (DU 800) for $150 \mathrm{~s}$ to establish a baseline slope before whole cell lysate was added ( 1 to $5 \mu \mathrm{L}$ ). The cuvettes were inverted once to mix and read an additional $450 \mathrm{~s}$. The decrease in absorbance over time was calculated and the baseline slope was subtracted. The NAD(P)H concentration was determined using the extinction coefficient (NADH: 6,220 $\mathrm{M}^{-1} \mathrm{~cm}^{-1}$, NADPH: 6,270 $\mathrm{M}^{-1} \mathrm{~cm}^{-1}$ ), and the specific activity was calculated as the change in $\mu \mathrm{mol}$ $\mathrm{NAD}(\mathrm{P}) \mathrm{H} / \mathrm{min} / \mathrm{mg}$ of whole cell lysate protein. Protein concentration was determined using the Bradford assay
(Bio-Rad, Hercules, CA) with bovine serum albumin as a standard. The specific activity was measured for the pET30a vector (control) and overexpressed Teth39_1597 and Teth39_1598 with acetaldehyde, butyraldehyde, isobutyraldehyde, furfural, and 5-HMF.

\section{Additional file}

Additional file 1: Table S1. Description of data. Proteomics data file for 225 proteins that were differentially regulated in response to a $15 \mathrm{mM}$ furfural treatment. Color-coded hierarchical cluster analysis, cluster number, cluster order, average $\mathrm{nSpC}$ per condition, fold change, and $P$-value are provided for all replicates. The raw output for all detected proteins and statistical analyses are also included.

\section{Abbreviations}

5-HMF: 5-hydroxymethylfurfural; ADH: alcohol dehydrogenase; AKR: Aldo/ keto reductase; ANOVA: analysis of variance; $\mathrm{BDH}$ : butanol dehydrogenase; CBP: consolidated bioprocessing; GC-MS: gas chromatography-mass spectrometry; HPLC: high performance liquid chromatography; IPTG: isopropyl- $\beta$ D-thiogalactopyranoside; LC-MS: liquid chromatography-mass spectrometry; nSpC: normalized spectral counts; OD: optical density; RP: reverse phase; SpC: spectral counts; TCA: tricarboxylic acid

\section{Competing interests}

The authors declare that they have no competing interests.

\section{Authors' contributions}

SMC, SDH-B, and JGE conceived and designed the study; SMC, SDH-B, and JGE performed growth experiments; SMC measured furan aldehydes; SMC and JGE performed HPLC analyses; SDH-B prepared samples for proteomic analysis; RJG and RLH performed proteomic experiments and statistical analyses; NLE and TJT performed GC-MS quantifications; SMC performed cloning and enzyme activity assays; SMC, RJG, and JGE analyzed the data and wrote the manuscript. All authors read and approved the final manuscript

\section{Acknowledgements}

We thank Sarah Kaufmann for laboratory assistance and Adam M. Guss for providing helpful comments on the manuscript. This work was supported by the BioEnergy Science Center (BESC), which is a U.S. Department of Energy Bioenergy Research Center supported by the Office of Biological and Environmental Research in the DOE Office of Science, Oak Ridge National Laboratory. Oak Ridge National Laboratory is managed by UT-Battelle, LLC, for the U.S. Department of Energy under contract DE-AC05-00OR22725. This manuscript has been authored by UT-Battelle, LLC, under Contract DE-AC05-00OR22725 with the U.S. Department of Energy. The United States Government retains, and the publisher by accepting the article for publication acknowledges, that the United States Government retains a non-exclusive paid-up, irrevocable, worldwide license to publish or reproduce the published form of this manuscript, or allow others to do so, for United States Government purposes.

\section{Author details}

${ }^{1}$ BioEnergy Science Center, Oak Ridge National Laboratory, Oak Ridge, TN 37831-6341, USA. ${ }^{2}$ Biosciences Division, Oak Ridge National Laboratory, Oak Ridge, TN 37831-6341, USA. ${ }^{3}$ Chemical Sciences Division, Oak Ridge National Laboratory, Oak Ridge, TN 37831-6341, USA. ${ }^{4}$ Current address: Division of Earth and Ecosystem Sciences, Desert Research Institute, Las Vegas, NV, USA

Received: 28 August 2014 Accepted: 7 November 2014 Published online: 03 December 2014

\section{References}

1. Wiegel J: Formation of ethanol by bacteria - a pledge for the use of extreme thermophilic anaerobic bacteria in industrial ethanol fermentation processes. Experientia 1980, 36:1434-1446. 
2. Taylor MP, Eley KL, Martin S, Tuffin MI, Burton SG, Cowan DA: Thermophilic ethanologenesis: future prospects for second-generation bioethanol production. Trends Biotechnol 2009, 27:398-405.

3. Lynd LR, Weimer PJ, van ZyI WH, Pretorius IS: Microbial cellulose utilization: fundamentals and biotechnology. Microbiol Mol Biol Rev 2002, 66:739-739.

4. Chung D, Cha M, Guss AM, Westpheling J: Direct conversion of plant biomass to ethanol by engineered Caldicellulosiruptor bescii. Proc Natl Acad Sci USA 2014, 111:8931-8936.

5. Bayer E, Shoham Y, Lamed R: Cellulose-decomposing bacteria and their enzyme systems. In The Prokaryotes. Volume 2. Part 1. Edited by Dworkin M, Falkow S, Rosenberg E, Schleifer K-H, Stackebrandt E. New York: Springer; 2006:578-617.

6. Lynd LR, Laser MS, Brandsby D, Dale BE, Davison B, Hamilton R, Himmel M, Keller M, McMillan JD, Sheehan, Wyman CE: How biotech can transform biofuels. Nat Biotechnol 2008, 26:169-172.

7. Olson DG, McBride JE, Shaw AJ, Lynd LR: Recent progress in consolidated bioprocessing. Curr Opin Biotech 2012, 23:396-405.

8. Alvira P, Tomas-Pejo E, Ballesteros M, Negro MJ: Pretreatment technologies for an efficient bioethanol production process based on enzymatic hydrolysis: a review. Bioresour Technol 2010, 101:4851-4861.

9. Hendriks A, Zeeman G: Pretreatments to enhance the digestibility of lignocellulosic biomass. Bioresour Technol 2009, 100:10-18.

10. Klinke HB, Thomsen AB, Ahring BK: Inhibition of ethanol-producing yeast and bacteria by degradation products produced during pre-treatment of biomass. Appl Microbiol Biotechnol 2004, 66:10-26.

11. Almarsdottir AR, Sigurbjornsdottir MA, Orlygsson J: Effect of various factors on ethanol yields from lignocellulosic biomass by

Thermoanaerobacterium AK17. Biotechnol Bioeng 2012, 109:686-694.

12. Zaldivar J, Martinez A, Ingram LO: Effect of selected aldehydes on the growth and fermentation of ethanologenic Escherichia coli. Biotechnol Bioeng 1999, 65:24-33.

13. Zaldivar J, Martinez A, Ingram LO: Effect of alcohol compounds found in hemicellulose hydrolysate on the growth and fermentation of ethanologenic Escherichia coli. Biotechnol Bioeng 2000, 68:524-530.

14. Martinez A, Rodriguez ME, York SW, Preston JF, Ingram LO: Effects of Ca $(\mathrm{OH})_{2}$ treatments ("overliming") on the composition and toxicity of bagasse hemicellulose hydrolysates. Biotechnol Bioeng 2000, 69:526-536.

15. Shaw AJ, Podkaminer KK, Desai SG, Bardsley JS, Rogers SR, Thorne PG, Hogsett DA, Lynd LR: Metabolic engineering of a thermophilic bacterium to produce ethanol at high yield. Proc Natl Acad Sci USA 2008, 105:13769-13774.

16. Shao XJ, Raman B, Zhu MJ, Mielenz JR, Brown SD, Guss AM, Lynd LR: Mutant selection and phenotypic and genetic characterization of ethanol-tolerant strains of Clostridium thermocellum. Appl Microbiol Biot 2011, 92:641-652.

17. Brown SD, Guss AM, Karpinets TV, Parks JM, Smolin N, Yang SH, Land ML, Klingeman DM, Bhandiwad A, Rodriguez M, Raman B, Shao XJ, Mielenz JR, Smith JC, Keller M, Lynd LR: Mutant alcohol dehydrogenase leads to improved ethanol tolerance in Clostridium thermocellum. Proc Natl Acad Sci USA 2011, 108:13752-13757.

18. Liu ZL, Blaschek HP: Biomass conversion inhibitors and in situ detoxification. In Biomass to Biofuels: Strategies for Global Industries. Edited by Vertès AA, Oureshi A, Blaschek HP, Yukawa H. West Sussex, United Kingdom: Wiley; 2010:233-259.

19. Liu ZL: Molecular mechanisms of yeast tolerance and in situ detoxification of lignocellulose hydrolysates. Appl Microbiol Biotechnol 2011, 90:809-825

20. Jonsson LJ, Alriksson B, Nilvebrant N-O: Bioconversion of lignocellulose: inhibitors and detoxification. Biotechnol Biofuels 2013, 6:16

21. Mills TY, Sandoval NR, Gill RT: Cellulosic hydrolysate toxicity and tolerance mechanisms in Escherichia coli. Biotechnol Biofuels 2009, 2:26.

22. Miller EN, Jarboe LR, Turner PC, Pharkya P, Yomano LP, York SW, Nunn D, Shanmugam KT, Ingram LO: Furfural inhibits growth by limiting sulfur assimilation in ethanologenic Escherichia coli strain LY180. Appl Environ Microbiol 2009, 75:6132-6141.

23. Miller EN, Jarboe LR, Yomano LP, York SW, Shanmugam KT, Ingram LO: Silencing of NADPH-dependent oxidoreductase genes (yqhD and $d k g A$ ) in furfural-resistant ethanologenic Escherichia coli. Appl Environ Microbiol 2009, 75:4315-4323.

24. Ahring BK, Licht D, Schmidt AS, Sommer P, Thomsen AB: Production of ethanol from wet oxidised wheat straw by Thermoanaerobacter mathranii. Bioresour Technol 1999, 68:3-9.
25. Georgieva Tl, Ahring BK: Evaluation of continuous ethanol fermentation of dilute-acid corn stover hydrolysate using thermophilic anaerobic bacterium Thermoanaerobacter BG1L1. Appl Microbiol Biotechnol 2007, 77:61-68.

26. Yao S, Mikkelsen MJ: Metabolic engineering to improve ethano production in Thermoanaerobacter mathranii. Appl Microbiol Biotechnol 2010, 88:199-208.

27. He Q, Hemme CL, Jiang HL, He ZL, Zhou JZ: Mechanisms of enhanced cellulosic bioethanol fermentation by co-cultivation of Clostridium and Thermoanaerobacter spp. Bioresour Technol 2011, 102:9586-9592.

28. Onyenwoke RU, Kevbrin W, Lysenko AM, Wiegel J: Thermoanaerobacter pseudethanolicus sp. nov., a thermophilic heterotrophic anaerobe from Yellowstone National Park. Int J Syst Evol Microbiol 2007, 57:2191-2193.

29. Bischoff KM, Liu SQ, Hughes SR, Rich JO: Fermentation of corn fiber hydrolysate to lactic acid by the moderate thermophile Bacillus coagulans. Biotechnol Lett 2010, 32:823-828.

30. de Vrije T, Bakker RR, Budde MAW, Lai MH, Mars AE, Claassen PAM: Efficient hydrogen production from the lignocellulosic energy crop Miscanthus by the extreme thermophilic bacteria Caldicellulosiruptor saccharolyticus and Thermotoga neapolitana. Biotechnol Biofuels 2009, 2:12.

31. Cao GL, Ren NQ, Wang AJ, Guo WQ, Xu JF, Liu BF: Effect of lignocellulosederived inhibitors on growth and hydrogen production by Thermoanaerobacterium thermosaccharolyticum W16. Int J Hydrogen Energy 2010, 35:13475-13480.

32. Delgenes JP, Moletta R, Navarro JM: Effects of lignocellulose degradation products on ethanol fermentations of glucose and xylose by Saccharomyces cerevisiae, Zymomonas mobilis, Pichia stipitis, and Candida shehatae. Enzyme Microb Technol 1996, 19:220-225.

33. Banerjee N, Bhatnagar R, Viswanathan L: Inhibition of glycolysis by furfural in Saccharomyces cerevisiae. Eur J Appl Microbiol Biotechnol 1981, 11:226-228.

34. Hemme CL, Fields MW, He Q, Deng Y, Lin L, Tu QC, Mouttaki H, Zhou AF, Feng XY, Zuo Z, Ramsay BD, He Z, Wu L, Van Nostrand J, Xu J, Tang YJ, Wiegel J, Phelps TJ, Zhou J: Correlation of genomic and physiological traits of Thermoanaerobacter species with biofuel yields. Appl Environ Microbiol 2011, 77:7998-8008.

35. Burdette DS, Vieille C, Zeikus JG: Cloning and expression of the gene encoding the Thermoanaerobacter ethanolicus 39E secondary-alcohol dehydrogenase and biochemical characterization of the enzyme. Biochem J 1996, 316:115-122

36. Burdette D, Zeikus JG: Purification of acetaldehyde dehydrogenase and alcohol dehydrogenases from Thermoanaerobacter ethanolicus $39 \mathrm{E}$ and characterization of the secondary-alcohol dehydrogenase $\left(2^{\circ} \mathrm{Adh}\right)$ as a bifunctional alcohol-dehydrogenase acetyl-CoA reductive thioesterase. Biochem J 1994, 302:163-170

37. Wilson CM, Yang S, Rodriguez M Jr, Ma Q, Johnson CM, Dice L, Xu Y, Brown SD: Clostridium thermocellum transcriptomic profiles after exposure to furfural or heat stress. Biotechnol Biofuels 2013, 6:131.

38. Ma M, Liu ZL: Comparative transcriptome profiling analyses during the lag phase uncover YAP1, PDR1, PDR3, RPN4, and HSF1 as key regulatory genes in genomic adaptation to the lignocellulose derived inhibitor HMF for Saccharomyces cerevisiae. BMC Genomics 2010, 11:660.

39. Gorsich SW, Dien BS, Nichols NN, Slininger PJ, Liu ZL, Skory CD: Tolerance to furfural-induced stress is associated with pentose phosphate pathway genes ZWF1, GND1, RPE1, and TKL1 in Saccharomyces cerevisiae. Appl Microbiol Biotechnol 2006, 71:339-349.

40. Lin F-M, Tan Y, Yuan YJ: Temporal quantitative proteomics of Saccharomyces cerevisiae in response to a nonlethal concentration of furfural. Proteomics 2009, 9:5471-5483.

41. Vizcaíno JA, Deutsch EW, Wang R, Csordas A, Reisinger F, Ríos D, Dianes JA, Sun Z, Farrah T, Bandeira N, Binz PA, Xenarios I, Eisenacher M, Mayer G, Gatto L, Campos A, Chalkley RJ, Kraus HJ, Albar JP, Martinez-Bartolomé S, Apweiler R, Omenn GS, Martens L, Jones AR, Hermjakob H: ProteomeXchange provides globally coordinated proteomics data submission and dissemination. Nature Biotechnol 2014, 30:223-226.

42. Lin FM, Qiao B, Yuan YJ: Comparative proteomic analysis of tolerance and adaptation of ethanologenic Saccharomyces cerevisiae to furfural, a lignocellulosic inhibitory compound. Appl Environ Microbiol 2009, 75:3765-3776.

43. Yang S, Giannone RJ, Dice L, Yang ZK, Engle NL, Tschaplinski TJ, Hettich RL, Brown SD: Clostridium thermocellum ATCC27405 transcriptomic metabolomic and proteomic profiles after ethanol stress. BMC Genomics 2012, 13:336. 
44. Peng $\mathrm{H}, \mathrm{Wu} \mathrm{G}$, Shao W: The aldehyde/alcohol dehydrogenase (AdhE) in relation to the ethanol formation in Thermoanaerobacter ethanolicus JW200. Anaerobe 2008, 14:125-127.

45. Petersson A, Almeida JRM, Modig T, Karhumaa K, Hahn-Hagerdal B, Gorwa-Grauslund MF, Liden G: A 5-hydroxymethyl furfural reducing enzyme encoded by the Saccharomyces cerevisiae ADH6 gene conveys HMF tolerance. Yeast 2006, 23:455-464.

46. Liu ZL, Moon J, Andersh BJ, Slininger PJ, Weber S: Multiple gene-mediated $\mathrm{NAD}(\mathrm{P}) \mathrm{H}$-dependent aldehyde reduction is a mechanism of in situ detoxification of furfural and 5-hydroxymethylfurfural by Saccharomyces cerevisiae. Appl Microbiol Biotechnol 2008, 81:743-753.

47. Yao S, Mikkelsen MJ: Identification and overexpression of a bifunctional aldehyde/alcohol dehydrogenase responsible for ethanol production in Thermoanaerobacter mathranii. J Mol Microbiol Biotechnol 2010, 19:123-133.

48. Miller TL, Wolin MJ: A serum bottle modification of the Hungate technique for cultivating obligate anaerobes. Appl Microbiol 1974, 27:985-987.

49. Wolin EA, Wolin MJ, Wolfe RS: Formation of methane by bacterial extracts. J Biol Chem 1963, 238:2882-2886.

50. Hamilton-Brehm SD, Mosher JJ, Vishnivetskaya T, Podar M, Carroll S, Allman S, Phelps TJ, Keller M, Elkins JG: Caldicellulosiruptor obsidiansis sp nov., an anaerobic, extremely thermophilic, cellulolytic bacterium isolated from Obsidian Pool, Yellowstone National Park. Appl Environ Microbiol 2010, 76:1014-1020.

51. Li YC, Tschaplinski TJ, Engle NL, Hamilton CY, Rodriguez M, Liao JC, Schadt CW, Guss AM, Yang YF, Graham DE: Combined inactivation of the Clostridium cellulolyticum lactate and malate dehydrogenase genes substantially increases ethanol yield from cellulose and switchgrass fermentations. Biotechnol Biofuels 2012, 5:2.

52. McDonald WH, Ohi R, Miyamoto DT, Mitchison TJ, Yates JR: Comparison of three directly coupled HPLC MS/MS strategies for identification of proteins from complex mixtures: single-dimension LC-MS/MS, 2-phase MudPIT, and 3-phase MudPIT. Int J Mass Spectrom 2002, 219:245-251.

53. Eng JK, McCormack AL, Yates JR: An approach to correlate tandem mass-spectral data of peptides with amino-acid-sequences in a protein database. J Am Soc Mass Spectrom 1994, 5:976-989.

54. Tabb DL, McDonald WH, Yates JR: DTASelect and Contrast: tools for assembling and comparing protein identifications from shotgun proteomics. J Proteome Res 2002, 1:21-26.

55. Giannone RJ, Huber H, Karpinets T, Heimerl T, Kuper U, Rachel R, Keller M, Hettich RL, Podar M: Proteomic characterization of cellular and molecular processes that enable the Nanoarchaeum equitans-Ignicoccus hospitalis relationship. PLoS One 2011, 6:e22942.

56. Lochner A, Giannone RJ, Keller M, Antranikian G, Graham DE, Hettich RL: Label-free quantitative proteomics for the extremely thermophilic bacterium Caldicellulosiruptor obsidiansis reveal distinct abundance patterns upon growth on cellobiose, crystalline cellulose, and switchgrass. J Proteome Res 2011, 10:5302-5314.

57. Zybailov B, Mosley AL, Sardiu ME, Coleman MK, Florens L, Washburn MP. Statistical analysis of membrane proteome expression changes in Saccharomyces cerevisiae. J Proteome Res 2006, 5:2339-2347.

doi:10.1186/s13068-014-0165-z

Cite this article as: Clarkson et al:: A comparative multidimensional LC-MS proteomic analysis reveals mechanisms for furan aldehyde detoxification in Thermoanaerobacter pseudethanolicus 39E. Biotechnology for Biofuels 2014 7:165.

\section{Submit your next manuscript to BioMed Central and take full advantage of:}

- Convenient online submission

- Thorough peer review

- No space constraints or color figure charges

- Immediate publication on acceptance

- Inclusion in PubMed, CAS, Scopus and Google Scholar

- Research which is freely available for redistribution 